
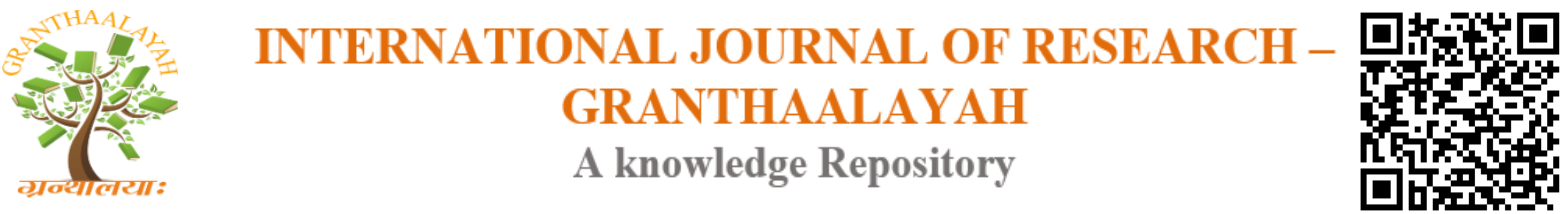

Social

\title{
A STUDY ON WORK-LIFE BALANCE OF NURSING STAFF WORKING IN PRIVATE HOSPITALS IN PALAYAMKOTTAI
}

\author{
G.Suguna ${ }^{1}$, C.Eugine Franco ${ }^{2}$ \\ ${ }^{1}$ Research Scholar, St. Xavier's College, Palayamkottai, India \\ ${ }^{2}$ Assistant Prof. \& Head, St. Xavier's College, Palayamkottai, India
}

\begin{abstract}
At present every successful employee has to pass through the dilemma of work life balance in personal and professional life. For the sake of leading a successful life, people do not hesitate to give extra time for achieving the objectives of life. In the process of getting extra mileage in their professional life they have to make a lot of compromise and sometimes mental piece also gets distorted. We have 24 hours at our disposal to deal with and it is up to us how to schedule and plan the same. It is rightly pointed out by experts, if our life span is 60 years (assumed to be) and if we sleep for 8 hours per day, than 20 years of our life span we used for sleeping only. So planning of our own time is important. At the end of the day priority matters a lot. In addition, relationships suffer and the person begins to experience loneliness and depression. The psychotherapist believes that mid-career professionals are most prone to having work-life imbalances. In the present paper it is an attempt by authors to present a study on work life balance dilemmas faced by nurses working in private hospitals. This study is based on primary sources of data and to some extent secondary sources. Various authentic journals, books and literature on the subject, newspapers, magazines, reports and studies were referred for the conceptual frame work of the study. The analysis is carried out on the basis of socio economic profile and general perception towards the personal and professional life.
\end{abstract}

Keywords: Work-life Balance; Hospitals; Personal \& Professoinal Life.

Cite This Article: G.Suguna, and C.Eugine Franco. (2017). "A STUDY ON WORK-LIFE BALANCE OF NURSING STAFF WORKING IN PRIVATE HOSPITALS IN PALAYAMKOTTAI." International Journal of Research - Granthaalayah, 5(8:SE), 72-75. https://doi.org/10.29121/granthaalayah.v5.i8(SE).2017.2250.

\section{Introduction}

Nowaday's, hospitals are confronting great competition and scarce resources than ever before. They are also severely challenged by the external and internal environment to achieve their goals effectively and efficiently. Nurses' are playing an important role in determining the quality and cost of healthcare. It is argued that they have the potential to be part of solutions to key problems in health care systems. Because, they are playing crucial role in their organizations performance 
and their family well-being. Nurses' work life balance is found to influence the hospital performance and productivity.

The tendency to become fully engaged in the performance of every role in ones total role system, to approach every typical role and role partner with an attitude of attentiveness and care. It is the practice of that even handed alertness know sometimes as mind fullness. However it is also noted that the expression of full engagement reflects a condition of "positive" role balance, in contrast to "negative" role balance in which individuals are fully disengaged in every role. It is understandably more concerned with positive role balance than negative role balance.

The word nursing comes from same root word „nutritious ${ }^{\text {ee }}$ means to nourish, to cherish, to protect, to support, to sustain, etc. It also means to train, to educate, to supply with the essentials of growth. Our work today as a nurse is a continuation of the work done by our parents, since the beginning of the time. Nursing in its simpler form existed from the beginning of human life and is essential to the maintenance of life. The first mother was the first nurse. From the time of the first mother down to the present day, we have found women protecting their children, and taking care of the elderly and sick members of the family. They also rendered their services to the neighbors during illness, Simple procedures for the sick were adopted, e.g., application of cold water over the forehead to reduce fever, application of pressure over a bleeding injury. Individuals who possessed special gifts and attitudes for caring and healing gradually collected a lot of healing knowledge through trial and error, and passed on from generation to generation. In ancient times, care and healing was considered to be the special responsibility of the priesthood or other religious groups. In the middle age, care of the sick was mainly the responsibility of military and religious orders.

The quality of service provided by the hospitals is of utmost importance for improving its inpatient rate and the nurses in the hospitals play a vital role maintaining this level of service. So in order to improve the quality of its service and organizational effectiveness hospitals must ensure high commitment from its patient-care personnel which is derived if they experience a sense of job satisfaction that is directly affected by their Quality of Work Life.

\section{Objectives of the Study}

The Purpose of the studies are,

- To find out the general perception of the nurses towards their personal and professional life.

- To provide suggestions to overcome work-life balance related to problems of nursing staff working in private and government hospitals.

\section{Result and Discussion}

Nurses' work life balance is an important factor because they are taking care of their family and also patients. Nurses are asked to rate themselves relating to their work life balance. Work life balance is measured with five statements with seven point scale their responses are coded and calculated the means score and standard deviation for each statement, the values are shown in the table -1 the mean score of balance of quality time is 3.89 . Ability to balance the work demands 
without unreasonable compromises of family responsibilities is secured a mean value of 4.21. Fulfilling personal life and adequately perform the work responsibility is secured the mean score of 4.62. The opinion of work life balance helps to provide work effectiveness and successful in the profession, with mean value of 6.21. Respondents are felt that a good work life balance helps to retain the medical profession with mean score of 6.52. The average mean score of work life balance factors is 5.09. It is found that nurses are believed that a good work life balance helps to retain in the profession and it provides effectiveness and success in their profession.

Table 1: Perception of Work Life Balance in Professional

\begin{tabular}{|l|l|l|l|}
\hline S.No & Statement & Mean & S.D \\
\hline 1 & Quality time between work and family & 3.89 & 0.96 \\
\hline 2 & Balance work demand without unreasonable & 4.21 & 1.26 \\
\hline 3 & $\begin{array}{l}\text { Satisfaction of personal life and adequate performance of work } \\
\text { responsibilities. }\end{array}$ & 4.62 & 0.81 \\
\hline 4 & $\begin{array}{l}\text { A good work-life balance provide a more effective and } \\
\text { successful medical profession. }\end{array}$ & 6.21 & 1.37 \\
\hline 5 & $\begin{array}{l}\text { A good work-like balance helps retain medical in the } \\
\text { profession. } \\
\text { Average mean }\end{array}$ & $\mathbf{5 . 0 9}$ & $\mathbf{1 . 0 9 2}$ \\
\hline
\end{tabular}

Work interfering with family is the second factor in measuring nurses opinion towards work interfering with family. It is necessary to calculate average score for work interfering with family responses to determine overall work life balance for the nurses. The results are displayed in the table 2. The average mean score of work interfering in the family life is 4.96 . It shows that nurses' agreed that work is interfering with their family life and also they felt that because of the work they may not spent more time with family or friends with mean score of 6.21.

Table 2: Perception of Work Life Balance in Personal

\begin{tabular}{|l|l|l|l|}
\hline S.No & Statement & Mean & S.D \\
\hline 1 & $\begin{array}{l}\text { After work, I come home too tired to do some of the things I'd } \\
\text { like to do. }\end{array}$ & 4.52 & 1.28 \\
\hline 2 & $\begin{array}{l}\text { On the job, I have so much work to do that it takes away from } \\
\text { my personal interests. }\end{array}$ & 3.85 & 1.62 \\
\hline 3 & $\begin{array}{l}\text { My family / friends dislike how often I am preoccupied with } \\
\text { my work while I am at home. }\end{array}$ & 0.92 \\
\hline 4 & $\begin{array}{l}\text { My work takes up time that I'd like to spend with } \\
\text { family/friends. }\end{array}$ & 6.21 & 1.02 \\
\hline & $\begin{array}{l}\text { Average mean } \\
\mathbf{4 . 9 6}\end{array}$ & $\mathbf{1 . 2 1}$ \\
\hline
\end{tabular}

\section{Conclusion}

Hospitals though preach different concepts on work life balance; it should at the same time practice it. Failing which they would lose the quality of the staff and their emotional attachment towards the hospitals and commitment towards the work. Hence, the top management of hospitals should aim at restructuring its policies whereby they can create a favorable working environment. Though women have made their way in to nursing profession, they still face some 
obstacles at their work places and at home. The findings of the study reveal that most of the nursing staff was dissatisfied with WLB. Family related issues and personal problems caused concern for nursing staff. Challenges persist at work places, and it is how nursing staff take these problems that are likely vary. Few issues are unique to female nursing staff and this need to prepare them to cope with these challenges and also hospital authorities can implement familyfriendly approaches to encourage nursing staff to balance their work-family challenges.

Dissatisfaction among nursing staff can be reduced by improving the quality of work life by providing an attractive system of rewards and recognition of good work and improving the working environment. Work-life balance issues have assumed a lot of importance in recent times due to increasing in single parent families, dual career couples and issues of elder care which create complex situations for the nursing staff. The factors that sustain or impede a healthy work life relationship are multifaceted and likely to differ depending on an individual's life circumstances, values and priorities. Managing both professional and personal life effectively and efficiently has become a major challenge for nursing staff employees. Innovative, robust and cost effective options will prove to be sustainable options in the long run and finally an instrument for competitive advantage. It is also true that these staffs are equally important for the growth of the organization. Their feelings, emotions and expectations cannot be taken for granted. Considering all the compulsions we can learn a lovely lesson from these lines, "Adjust ourselves in every situation and in any shape but the most important is to always find out our own way to flow."

\section{References}

[1] Anderson, S.E., "Formal Organizational Initiatives and Informal Work place practices: Link to work family conflict and job related outcomes", Journal of Management, Vol.28, Issue 6, pp.787810, 2002.

[2] Blau, G. J., Paul, A., \& St. John, N. On developing a general index of work commitment. Journal of Vocational Behavior, 42(3), 298-314.

[3] Golden, S. A. R. (2017). Recent Research in Social Sciences \& Humanities. EduPedia Publications (P) Ltd.

[4] Manonmani, M. Employment, Output and Wage Elasticity in Research Intensive Industries in India. Recent Research in Social Sciences \& Humanities, 69.

[5] Regi, S. B. (2016). Prospectus \& Challenges Of Women Entrepreneurs-A Study With Special Reference To Tirunelveli District. International Journal Of Scientific Research And Modern Education, 786, 792.

[6] Regi, S. B., Golden, S. A. R., \& Franco, C. E. (2014). Employee Perception Towards Effectiveness Of Hr Practices In Public Sector Banks In Tirunelveli District. Tactful Management Research Journal, 2(6), 1-4.

[7] Regi, S. B., Golden, S. A. R., \& Franco, C. E. (2014). Self-Employment As Sustainable Employment"-A Study On Self Employed Women's Association (Sewa) Gujarat, India. Indian Streams Research Journal, 4 (2), 1, 5.

[8] Sipos, L., \& Tóth, A. (2007). Rational approach in Hungarian mineral water market. Hungarian Electronic Journal of Sciences, 1-9. 